\title{
Public Service Motivation (PSM) and Job Satisfaction in Case of Hungarian Local Public Service
}

\author{
Gábor HOLLÓSY-VADÁSZ1
}

\begin{abstract}
Public Service Motivation (PSM) originates from psychology and it spreads in other disciplines such as public administration. PSM was developed in the USA and it is also applied in Europe. In this study, I investigated the connection between PSM, job satisfaction, red tape, and resignation satisfaction in case of a Mayor's office of a district in Budapest. I had four hypotheses but I could prove only one. I found a significant connection between PSM factors and job satisfaction. These results may suggest that PSM could affect how public servants are satisfied with their job in the Hungarian public service.
\end{abstract}

Keywords: Public Service Motivation, PSM factors, job satisfaction, correlation, regression analysis, motivators

\section{Introduction}

Public Service Motivation as a theory originates from psychology and it spreads in other disciplinaries like socio-biology, economics, organizational behaviour, sociology, political science and public administration. [1] PSM was developed in the USA and also applied in Europe. [2] PSM was inspired by New Public Management and it turned up in the 90's. "PSM is the motivational force that induces individuals to perform meaningful public service.” [3: 417] The special motives in public service: [4]

1. Rational: PSM pays attention that public servants behave in an altruistic way but they also want to maximize their utility.

2. Norm-based: the main norm in public sector is to service the public interest.

3. Affective: the main element of the affective norm is patriotism of benevolence which refers to the fact that professionals in public service must provide safety to citizens based on basic rights.

Four dimensions of PSM: [5]

1. Attraction to public policy making refers to be exciting to participate in policy making.

2. Commitment to the public interest refers to the desire to service in the public sector which is an altruistic behaviour.

3. Compassion equals to the patriotism of benevolence which is a moral attitude and an emotional stand. Here, compassion refers to provide the basic rights without screening the political preferences or political attitudes of the citizens.

4. Self-sacrifice is "the willingness to substitute service to others for tangible personal rewards”. [5: 7]

Ph.D. student, National University of Public Service; e-mail: hvadaszg@gmail.com 
In this study, I examine the connection between PSM, job-satisfaction, resigned satisfaction, and red tape. The number of studies examining job-satisfaction have been continuously increasing in the last 40 years. Job satisfaction can modify significantly both the employees' and the organizations' performance. Job satisfaction is also important due to humanitarian reasons. Job satisfaction goes with mental and physical health. [6]

Resigned satisfaction is not a popular research area in public administration. The authors claim the resigned satisfaction is a part of job satisfaction. They defined resigned satisfaction, which is an individual sense that origins from the difference between his/ her personal goals and his/her current job status. If individual experiences are in harmony with his/her personal goals and his/her current job status then her or his aspiration to work will increase. If individual experiences are in disharmony with his/her personal goals and his/her current job status then her or his aspiration will decrease. That can be a stresssource. [7]

Red tape refers to a couple of rules, procedures, regulations that do not create beneficial situations. These situations decrease the loyalty to the organizations. Therefore, not all regulations are red tapes, just those that obstruct the employees. Red tape correlates to high insecurity, mistrust, pessimism. [7]

\section{Previous PSM and Hungarian Motivation Studies}

In this section of the study, I summarize the results of previous related studies which applied regression models to search for the connection between PSM and job satisfaction. [8] Numerous studies investigated the relationship between PSM and various labels (such as job satisfaction) in this decade. The authors referred to 28 studies but I will refer only to the most relevant articles. [8] The national context could modify the relationship between PSM and job satisfaction.

Firstly, I refer to a cross-cultural study. [6] A previous study used the data of International Social Survey Program on Work Orientations which included six different countries: Germany, Great Britain, the USA, Hungary, Norway and Israel. The authors found the intrinsic rewards (for example autonomy) had the strongest effect on job satisfaction. PSM-fit (compatibility between individual PSM and features of work environment) had a positive effect on job satisfaction. The results suggested that there was no significant correlation between PSM and job satisfaction. [6] Public servants who experienced a smaller gap between PSM and an opportunity to realize their motives were more satisfied with their jobs than public servants who believed they could not do it. In case of Hungary, the authors found the major drivers of job satisfaction (intrinsic and extrinsic rewards) were scored lower by Hungarian respondents than in other countries.

The above-mentioned article was a cross-cultural study so I present a study which examined only one country. I previously referred to a study [7] that tested the connection between PSM, red tape and resigned satisfaction using a regression model. The responders were Swiss public servants speaking French or German. According to the results, Compassion and Self-sacrifice (PSM factors, see above) can be factors of resignation. Commitment and Attraction to public policy do not correlate with resignation. This result refers to a psychological contract between public servants and public organizations. The psychological 
contract is "a subjective perception of the employment relationship and is mainly concerned with expectations about the mutual obligations of employer and employee to the relationship." [7: 188] The resigned satisfaction is the manifested outcome of breaking the common psychological contract. Another important result of the study is that red tape strengthens the resigned satisfaction.

The above-mentioned articles did not investigate the mediation effect of PSM so I present a study investigating the mediation effect of PSM. [9] The author investigated the relationship between job satisfaction and organizational commitment in case of a Belgian public service. The study also investigated the mediation effect of PSM. According to the results, three PSM factors (Attraction to public policy making, Commitment to the public interest, Self-sacrifice) went with self-reported performance. Compassion did not meet to a professional public administration where it was not allowed to behave compassionately. He hypothesized that job satisfaction and organizational commitment could modify the relationship between PSM and performance. According to his results, the above-mentioned mediators went with all PSM factors. Finally, PSM could produce person-environment fit in the public sector that created satisfaction among the public servants.

In this paragraph, I present the results of the Hungarian motivation studies in public service. In the Hungarian public service [10] there are three different categories of motivation ideas. The first cluster is called 1.0. According to the ideas of the first cluster, motivation is only the satisfaction of biological needs so, a public organization can motivate the public servants only by the satisfaction of biological needs. The second cluster is called 2.0. According to the ideas of the second cluster, employees are interested in avoiding the penalty and they are motivated in searching for rewards. So, these kinds of theories use only outside motivators. The third cluster is called 3.0. The ideas of the third cluster suggest using the inside motivators also. This can be a connection point between Hungarian public service and PSM because PSM also suggests adopting and using the inside motivators. [11] Hungarian authors define the motivation as an intrapersonal drive which is closed to the motivation concept of PSM.

\section{The Goals and Hypotheses of this Study}

In the Hungarian public service literature, one cannot find any empirical studies using the PSM concept. [12] Therefore, no Hungarian study investigated the connection between PSM and job satisfaction. The main goal of this study is to investigate the connection between PSM and job satisfaction in case of Hungarian local governments. I have three hypotheses:

1. There are positive correlations between some PSM factors and job satisfaction, according to a previous study. [7]

2. There are positive correlations between some PSM factors and resigned satisfaction according to a previous study. [7]

3. Red tape strengthens the resigned satisfaction according to a previous study. [7] 


\section{Methods}

I developed a questionnaire which includes four different parts:

1. In the first part of the questionnaire, there are items investigating the demographical status of the respondents such as gender, age, highest level of their education and residence. In this part of the questionnaire the respondents also answered some questions in line with their jobs such as: $a$ ) What time did they start working in public service? b) When did they start working at their current job? c) In what hierarchical system do they work?

2. In the second part of the questionnaire, there is a Likert scale to measure the overall job satisfaction.

3. In the third part of the questionnaire, there are scales developed by a previous study to measure PSM factors. [7] The questionnaire includes 4 factors. The first factor includes 2 scales. The second factor includes 4 scales. The third factor includes 3 scales. The fourth factor includes 2 scales. The items were translated into Hungarian.

4. In the fourth part of the questionnaire, there are scales developed by a previous study [7] to measure red tape and resigned satisfaction. The red tape questionnaire includes 3 factors. The resigned satisfaction questionnaire includes 4 factors. The items were translated into Hungarian.

All items of the questionnaire were in the Hungarian language.

\section{Respondents}

( $n=40)$ public servants filled my questionnaires worked in a Mayor's office of a district in Budapest. ( $n=12 ; 28.6 \%$ ) of the respondents were men and ( $n=28 ; 66.7 \%$ ) of the respondents were women. The average age of the respondents is $(m=42.78$ year; $\mathrm{SD}=9.344$ year). Table 1 presents the hierarchical level of the employees in public organizations. $73.8 \%$ of the respondents were subordinate workers. Table 2 presents the educational level of the employees. The lowest educational level of the respondents was high school, the highest educational level of the respondents was MA/MSc degree.

Table 1. Hierarchical level of the employees. [Edited by the author.]

\begin{tabular}{|l|c|c|}
\hline Hierarchical level & Number of employees & Percentage \\
\hline Top managers & 3 & $7.1 \%$ \\
\hline Middle managers & 4 & $9.5 \%$ \\
\hline Professional advisers & 2 & $4.8 \%$ \\
\hline Subordinate workers & 31 & $73.8 \%$ \\
\hline Summarized & 40 & $100 \%$ \\
\hline
\end{tabular}


Table 2. Educational level of the employees. [Edited by the author.]

\begin{tabular}{|l|c|c|}
\hline Educational level & Number of employees & Percentage \\
\hline High school & 3 & $7.1 \%$ \\
\hline Professional qualification & 9 & $21.4 \%$ \\
\hline BA/BSc & 15 & $35.7 \%$ \\
\hline MA/MSc & 13 & $31.0 \%$ \\
\hline Summarized & 40 & $100 \%$ \\
\hline
\end{tabular}

\section{Results}

Firstly, I controlled the reliabilities of PSM, red tape and resigned satisfaction. Table 3 presents the Cronbach Alpha scores. Cronbach Alpha scores must be over 0.7. If it is not over 0.7 that means, the questionnaire is not reliable, therefore, I ignore any other statistical examinations of red tape and resigned satisfaction in this study.

Table 3. Cronbach Alpha scores. [Edited by the author.]

\begin{tabular}{|l|c|}
\hline Name of dimension & Cronbach Alpha \\
\hline PSM & 0.780 \\
\hline Red Tape & 0.571 \\
\hline Resigned Satisfaction & 0.297 \\
\hline
\end{tabular}

Secondly, I tested the connection between PSM factors and job satisfaction in a linear regression model based on entry method. In this case, $\left(\mathrm{R}^{2}=0.417 ; \mathrm{p}<0.001\right)$. Table 4 presents the regression model based on entry methods. Commitment to the public interest is only one factor that affects significantly on job satisfaction.

Table 4. The regression model based on entry method. [Edited by the author.]

\begin{tabular}{|l|c|c|}
\hline Model & Beta & Significance \\
\hline PSM Factor 1 & -0.092 & 0.510 \\
\hline PSM Factor 2 & 0.466 & $0.010^{*}$ \\
\hline PSM Factor 3 & 0.082 & 0.610 \\
\hline PSM Factor 4 & 0.203 & 0.262 \\
\hline
\end{tabular}

${ }^{*} \mathrm{p}<0.05$

Thirdly, I investigated the internal correlation between PSM factors and job satisfaction. I found 4 significant correlations. The PSM Factor 2 (Commitment to the public interest) has 
the strongest effect on job satisfaction. The PSM Factor 3 (Compassion) and PSM Factor 4 (Self-sacrifice) have also a strong effect on job satisfaction. The PSM factor 1 (Attraction to public policy making) dos not have a significant effect on job satisfaction. Table 5 presents the correlation results.

Table 5. Correlations between PSM factors and job satisfaction. [Edited by the author.]

\begin{tabular}{lc}
\hline Name of PSM factors and scales & Job satisfaction \\
\hline PSM Factor 1 & 0.069 \\
PSM Factor 2 & $0.616^{* *}$ \\
PSM Factor 3 & $0.440^{* *}$ \\
PSM Factor 4 & $0.493^{* *}$ \\
\hline
\end{tabular}

${ }^{*} \mathrm{p}<0.005 ;{ }^{* *} \mathrm{p}<0.01$

\section{Discussion}

No empirical studies using PSM concept is to be found in the Hungarian public service literature. There is only one Hungarian study that focuses on PSM but that is a theoretical study. [12] This is one of the first studies that empirically investigates PSM in the Hungarian public service. In this study, I investigated the connection between PSM and job satisfaction in case of a Hungarian local public sector. The respondents worked in a Mayor's office of a district in Budapest. The Cronbach Alfa scores of red tape and resigned satisfaction are under 0.7 . There could be two reasons for the low reliabilities. The first one might be that only 40 people participated in this study. The low number of respondents is the main limitation of this study. Red tape's Cronbach Alfa score proves the above-mentioned idea because it is close to the acceptable level. The second reason might be that resigned satisfaction concept does not fit into the Hungarian public sector. In the future, some studies should investigate if resigned satisfaction concept can adapt and apply in the Hungarian public sector. However, I had three hypotheses but I could prove only the first one because the red tape and resigned satisfaction could not be statistically analysed.

Although the number of respondents is limited, still I could successfully prove my first hypothesis. Three PSM factors positively correlate to the job satisfaction. If employees score high on Commitment to the public interest, Compassion and Self-sacrifice, they are satisfied with their current jobs. Therefore, public organizations should seek for employees who are committed to the public interest, have compassion and willingness to serve others because these servants are satisfied with their public jobs. My results confirm a previous study [7] that found positive correlations in Switzerland. According to regression results, the PSM Factor 2 can explain $41.7 \%$ of job satisfaction's variance but the other PSM factors do not have significant effects on job satisfaction. The results of correlation and regression analyses suggest that the PSM concept can strongly modify how Hungarian public servants are satisfied with their jobs. My results partially disprove a previous study [6] that found 
significant connection between PSM-fit and job satisfaction in their cross-cultural study. I suppose the reason is that the connection can be modified by the national context. [8]

A Hungarian study [13] summarized the managerial responsibilities in the Hungarian public service. The author mentioned that the main responsibilities of managers are to motivate the employees in public sector. One of the main goals of Public Administration and Public Service Development Strategy 2014-2020 [14] is that public employees in the Hungarian public administration should be motivated on high level because it is one of the principles of the Good State Conception. [14] The results of this study and the whole PSM concept can support these processes and there is empirical evidence that PSM is a valid concept in the Hungarian public administration.

\section{References}

[1] KOEHLER, M., RAINEY, H. G.: Interdisciplinary foundations of public service motivation. In. PERRY, J. L., HONDEGHEM, A. (eds.): Motivation in Public Management. The Call of Public Service. Oxford: Oxford University Press, 2008, 33-55.

[2] MIHALCIOIU, R. M.: Public service motivation. EIRP Proceedings, 6 (2011), 834-838.

[3] BREWER, G., COLEMAN SELDEN, S.: Whistle blowers in the federal civil service: new evidence of the public service ethic. Journal of Public Administration Research and Theory, 83 (1998), 413-439.

[4] PERRY, J. L., WISE, L. B.: The Motivational Bases of Public Service. Public Administration Review, 503 (1990), 367-373. https://doi.org/10.2307/976618

[5] PERRY, J. L.: Measuring Public Service Motivation: An Assessment of Construct Reliability and Validity. Journal of Public Administration Research and Theory, 61 (1996), 5-22. https://doi.org/10.1093/oxfordjournals.jpart.a024303

[6] WESTOVER, J. H., TAYLOR, J.: International differences in job satisfaction. The effects of public service motivation, rewards and work relations. International Journal of Productivity and Performance Management, 598 (2010), 811-828.

[7] GIAUQUE, D., RITZ, A., VARONE, F., BIGET, S. A.: Resigned but satisfied: the negative impact of public service motivation and red tape on work satisfaction. Public Administration, 901 (2012), 175-193. https://doi.org/10.1111/j.1467-9299.2011.01953.x

[8] HOMBERG, F., MCCARTHY, D.: A Meta-Analysis of the Relationship between Public Service Motivation and Job Satisfaction. Public Administration Review, 755 (2015), 711722. https://doi.org/10.1111/puar.1242

[9] VANDENABEELE, W.: The mediating effect of job satisfaction and organizational commitment on self-reported performance: more robust evidence of the PSM-performance relationship. International Review of Administrative Sciences, 7511 (2009), 11-34.

[10] SZAKÁCS G.: Az emberi erőforrás gazdálkodás fejlesztésének elméleti kérdései a magyar közszolgálatban. Budapest: Nemzeti Közszolgálati Egyetem Közigazgatás-tudományi Kar, 2014.

[11] SZABÓ Sz., SZAKÁCS G.: Közszolgálati HR-Menedzsment. Budapest: Nemzeti Közszolgálati Egyetem Közigazgatás-tudományi Kar, 2015.

[12] HOLLÓSY V. G., SZABÓ Sz.: A pszichológiai megközelítésű PSM-paradigma jelentősége a magyar közszolgálatban. Hadtudományi Szemle, 92 (2016), 163-174. 
G. HOLLÓSY-VADÁSZ: Public Service Motivation (PSM) and Job Satisfaction...

[13] SZABÓ Sz.: Managerial Responsibility and Efficiency in Public Service (Competencybased Solutions). AARMS, 153 (2016), 271-277.

[14] Közigazgatás- és Közszolgáltatás-fejlesztési Stratégia 2014-2020. www.kormany. hu/download/8/42/40000/K\%C3\%B6zigazgat\%C3\%A1s_feljeszt\%C3\%A9si_ strat\%C3\%A9gia_.pdf (Downloaded: 01.09.2017) 